\title{
Budaya "Pakewuh" Santri pada Kyai: Relevansi Budaya Pendidikan Pesantren terhadap Tantangan Dunia Islam di Era Globalisasi
}

\section{Baiqun Isbahi}

Social Science and Political Science Faculty Universitas Darul 'Ulum Jombang baiqunbai@gmail.com

\section{Novy Setia Yunas}

Political Science and Social Science Universitas Islam Negeri Sunan Ampel Surabaya novysetiayunas@gmail.com

\begin{abstract}
The phenomenon of communication process in pesantren occurs among kyai, ustadz, and santri creating a distinctive educational culture among pesantren. The relationship among them is very close, because santri permanently live in a pesantren environment nearby the kyai's house. Europe in the mid-century is full of power, doctrine and domination of the church which has purpose to guide people towards a righteous life, but on the other hand the dominance of this church without thinking of the dignity and freedom of human beings who have feelings, thoughts, desires and ideals to determine his own future, therefore the development of science is inhibited. Meanwhile, the culture of education in pesantren raises a similar similarity though not the same, where the position of kyai is considered as the representative of the god who escaped the error. Both of these phenomena are presenting the dominance of the religious doctrine that can penetrate the layers of public confidence in various areas of life. Based on the study, it can be concluded that the leadership in pesantren with the "pekewuh" culture of Islamic religious figures (kyai) is found in the traditional society, and the leadership in the transitional society-especially in modern society and the metropolis-has experienced a crisis of legitimacy, irrelevant sense in the era of globalization, and degradative change, due to the various dynamics and changes that occur, both internal and external dynamics of the Muslim community.
\end{abstract}

Keywords: Pekewuh, pesantren, globalization

\section{Abstrak}

Fenomena proses komunikasi di pesantren terjadi antara kyai, ustadz, dan santri melahirkan sebuah budaya pendidikan yang khas di kalangan pesantren. Hubungan di antara mereka sangat erat, karena seorang santri secara permanen hidup dalam lingkungan pesantren dan dekat dengan rumah kyai. Eropa di abad pertengahan 
Millatī, Journal of Islamic Studies and Humanities, Vol. 3, No. 1, Juni 2018: 103-124

yang kental dengan kekuasaan dan doktrin gereja dan dominasi gereja yang tujuannya untuk membimbing umat kearah hidup yang saleh, namun disisi lain dominasi gereja ini tanpa memikirkan martabat dan kebebasan manusia yang mempunyai perasaan, pikiran, keinginan, dan cita-cita untuk menentukan masa depannya sendiri, karena itu perkembangan ilmu pengetahuan terhambat. Sementara, budaya pendidikan di pesantren memunculkan sebuah kesamaan yang mirip meski tidak sama, dimana posisi kyai dianggap sebagai wakil tuhan yang terhindar dari kesalahan. Sehingga kedua fenomena tersebut saling menyuguhkan dominasi sisi doktrin agama yang mampu menembus lapisan kepercayaan masyarakat dalam berbagai bidang kehidupan. Berdasarkan kajian dapat disimpulkan bahwa kepemimpinan di pesantren dengan budaya "pekewuh" tokoh keagamaan Islam (kyai) terdapat pada masyarakat yang masih tradisional dan kepemimpinan tersebut pada masyarakat transisi -apalagi pada masyarakat modern dan masyarakat metropolis- telah mengalami krisis legitimasi, irrelevant sense di era globalisasi, dan perubahan secara degradatif, karena berbagai dinamika dan perubahan yang terjadi, baik yang bersifat internal pesantren maupun dinamika eksternal komunitas Muslim.

Kata Kunci: Pekewuh, pesantren, globalisasi

\section{Pendahuluan}

Kebudayaan merupakan keseluruhan sistem gagasan, tindakan dan hasil karya manusia dalam kehidupan masyarakat yang dijadikan milik diri manusia dengan belajar. Kebudayan memiliki tiga wujud yaitu wujud kebudayaan sebagai suatu kompleks dari ide, gagasan, nilai, norma, peraturan, dan sebagainya; wujud kebudayaan sebagai suatu kompleks aktivitas serta tindakan berpola dari manusia dalam masyarakat; wujud kebudayaan sebagai benda-benda hasil karya manusia. Selain itu menurut Kluckhohn (1953) kebudayaan juga memiliki unsur-unsur, unsur itu terdiri dari unsur bahasa, sistem pengetahuan, organisasi sosial, sistem peralatan hidup dan teknologi, sistem mata pencaharian hidup, sistem religi, dan kesenian. ${ }^{1}$

Berbicara mengenai kebudayaan, pasti merujuk pada salah satu kiblat kebudayaan dunia yaitu kebudayaan Eropa. Bermula dari peradaban Yunani hingga dilanjutkan peradaban Romawi dengan berbagai macam kebudayaan yang dihasilkan tentunya. Berbagai macam kebudayaan yang muncul pada kedua zaman itu telah banyak memberi sumbangsih pada perkembangan kebudayaan

${ }^{1}$ C. Kluckhohn, Universal Categories of Culture; Antropology Today, A.L Kroeber Editor, (Chicago: University Press, 1953), h. 90. 
di dunia.Setelah zaman itu munculah zaman dimana orang menyebutnya zaman kegelapan, zaman tidak berkembangnya ilmu pengetahuan dan lebih dominannya doktrin-doktrin gereja. Sebutan lain untuk zaman ini ialah Abad Pertengahan, abad kegelapan Eropa dan juga awal berjayanya kebudayaan Eropa. Hal ini cukup menarik dimana ketika masyarakat Eropa terjatuh dalam keterpurukan, namun mereka dapat kembali bangkit dari keterpurukan itu serta dapat kembali seperti masa kejayaan Romawi atau Yunani.

Di sisi lain, perkembangan peradaban Islam pun dimulai sejak abad ke7 Masehi, ketika masyarakat islam kala itu dipimpin oleh Khulafa' al-Rasyidin. ${ }^{2}$ Kemudian mulai berkembang pada masa Dinasti Umayyah, dan mencapai puncak kejayaannya pada masa Dinasti Abbasiyah. Ketinggian peradaban Islam pada masa Dinasti Abbasiyah merupakan dampak positif dari aktifitas kebebasan berpikir umat Islam kala itu yang tumbuh subur ibarat cendawan di musim hujan. Setelah jatuhnya Dinasti Abbasiyah pada tahun $1258 \mathrm{M}$, peradaban Islam mulai mundur. Hal ini terjadi akibat dari merosotnya aktifitas pemikiran umat Islam yang cenderung kepada ke-jumud-an (stagnan). Setelah berabad-abad umat Islam terlena dalam "tidur panjangnya”, maka pada abad ke-18 M mereka mulai tersadar dan bangkit dari stagnasi pemikiran untuk mengejar ketertinggalannya dari dunia luar dalam hal ini Barat atau Eropa. Kala itu, perkembangan pemikiran dan kebudayaan Islam ini karena didukung oleh para khalifah yang cinta ilmu pengetahuan dengan fasilitas dan dana secara maksimal, stabilitas politik dan ekonomi yang mapan. Di samping itu berkembang juga ilmu-ilmu sosial dan eksakta, seperti filsafat, logika, metafisika, bahasa, sejarah, matematika, ilmu alam, geografi, aljabar, aritmatika, mekanika, astronomi, musik, kedokteran dan kimia. Ilmu-ilmu eksakta melahirkan teknologi yang sangat dibutuhkan dalam menunjang peradaban umat Islam. ${ }^{3}$

Pada perkembangan islam di Indonesia, peradaban dan kebudayaannya banyak dipengaruhi oleh eksistensi pesantren khususnya di Jawa Timur. Sebuah pesantren diasuh atau dipimpin oleh seorang kyai /gus. Sang kyai /gus memiliki beragam peran dalam pesantren, misalnya: sebagai pemilik, pengawas, penanggungjawab, pendidik, pengajar, dan pengendali. Hiroko Horikoshi

2 Sebagai contoh: pada masa Khulafa' al-Rasyidin sudah lahir pemikiran Islam, seperti kitab Nahj al-Balaghah karya Imam Ali Bin Abi Thalib. (http://hminews.com/news/ bangkrutnya-tradisi-intelektual-islam redesain gerakan - intelektual-sistemik-nasional/. Diunduh tanggal 20 Maret 2018

${ }^{3}$ M. Abdul Karim, Sejarah Pemikiran dan Peradaban Islam, cetakan II, (Yogyakarta: Penerbit Pustaka Book Publisher, 2009), h. 173-175. 
Millatī, Journal of Islamic Studies and Humanities, Vol. 3, No. 1, Juni 2018: 103-124

(1987) mendeskripsikan kyai menduduki posisi sentral dalam masyarakat Islam tradisional dan dapat menyatukan berbagai golongan hingga mampu melakukan tindakan kolektif, jika diperlukan. ${ }^{4}$ Mengambil peran sebagai poros interaksi antara umat dengan Tuhan.Menjadi contoh Muslim yang hendak dicapai. Seseorang yang dianugerahkan pengetahuan dan rahmat.Sifat hubungan antara kyai dan masyarakat adalah kolektif.

Kyai mewarisi kekuasaan yang bersumber dari kharisma, terkesan sebagai pemimpin simbolis yang tidak gampang ditiru oleh orang biasa. Para kyai adalah orang yang paling tinggi strata dan wibawanya di kalangan umat. Dalam mengoreksi kesalahan umat, seorang kyai tidak pernah mengatakan bahwa seseorang telah bersalah. Ia melakukannya dengan jalan mengisahkan cerita lama, yang mana seseorang dapat menyimpulkan kesalahannya sendiri tanpa harus mengatakan salah secara langsung. ${ }^{5}$

Sedangkan istilah santri biasanya digunakan untuk menyebut siswa yang belajar di sekolah agama (madrasah) atau pondok pesantren. Kata santri diadopsi dari bahasa India yaitu shastri yang berarti orang yang mengetahui dan memahami kitab-kitab suci (dalam agama Hindu). Dalam kultur Jawa menyebut santri dengan "putihan".Berasal dari kata dasar "putih" yang mendapatkan akhiran "an”.Kata ini diambil dari warna pakaian dan kopiah yang dipakai oleh para santri saat shalat berjamaah dan berangkat mengaji, yaitu warna putih. ${ }^{6}$

Clifford Geertz (2013) menguraikan penghuni pesantren selain kyai dan ustadz adalah santri sebagai peserta didik. Saat ini, kebanyakan para santri tinggal di pondok yang menyerupai asrama biara, yang mana mereka hidup mandiri dengan memasak dan mencuci pakaiannya sendiri. Meskipun pondok mengingatkan pada biara, santri bukanlah pendeta.Seorang santri bukanlah orang suci yang magang.Ia hanya seorang anak-anak atau remaja yang menjadi dewasa di dalam lingkungan keagamaan. Menjadidewasa dengan gemuruh pengajianyang terdengar di telinga dan nampak terlihat di matanya. ${ }^{?}$

Pesantren berarti lembaga pendidikan Islam yang pada umumnya

${ }^{4}$ Hiroko Horikoshi, Kyai dan Perubahan Sosial, (Jakarta: P3M, 1987), h. 232.

${ }^{5}$ Bryan S. Turner, Sosiologi Islam: Suatu Telaah Analisis atas Tesa Sosiologi Weber, Terj. Machnun Husein, (Jakarta: Rajawali, 1984), h. 168-169. lihat juga Benedict ROG Anderson, Gagasan tentang Kekuasaan dalam Kebudayaan Jawa, Terj. Ali As'ad, (Semarang: Menara Kudus, 1972), h. 32-33.

${ }^{6}$ Zaini Muchtarom, Santri dan Abangan di Jawa, (Jakarta: INIS, 1988) h. 6.

${ }^{7}$ Clifford Geertz, Agama Jawa: Abangan, Santri, Priyayi Dalam Kebudayaan Jawa, (Jakarta: Komunitas Bambu, 2013), h. 255-256. 
penyelenggaraan pendidikan dan pengajarannya diberikan dengan cara nonklasikal (sistem bandongan dan sorogan), di mana seorang kyai mengajar santri-santrinya berdasarkan kitab-kitab yang ditulis. Menurut Dhofier (1982) pesantren merupakan lembaga pengajian yang mempunyai lima elemen dasar, yaitu masjid, kyai, santri, pondok, dan pengajaran kitab-kitab Islam klasik. ${ }^{8}$ Sebagai contoh Pesantren Langitan termasuk dalam kategori pesantren tertua (karena umurnya yang sudah satu setengah abad). Pesantren Langitan didirikan oleh KH. Muhammad Nur pada 1852 M. Semangat dan tujuan yang ikhlas dan luhur untuk mendirikan pesantren ini tercapai dengan menghasilkan putradan putrinya sebagai kader, yang akan meneruskan semangat dan cita-cita luhurnya.

Sistem pengajaran di Pesantren Langitan masih mempertahankan model salafi, yaitu pengajaran kitab-kitab Islam klasik sebagai inti pendidikan di pesantren. Metode yang digunakan dalam mengajar di Pesantren Langitan adalah metode klasikal (madrasiyyah) dan nonklasikal (ma'hadiyyah), yang meliputi metode bandongan, wetonan, sorogan, musyâwarah, dan muhâfazhah . Karakteristik pengaturan pesantren yang turun temurun hampir terjadi disemua pesantren di Indonesia umumnya, khususnya di Jawa Timur. Di Prenduan, Sumenep, Tambakberas Jombang, dan Sidogiri Pasuruan adalah model pesantren salaf yang masih kental dengan sistem pengajaran dan karakteristik kepemimpinan yang khas yang masih dipertahankan.

Fenomena proses komunikasi di pesantren terjadi antara kyai, ustadz, dan santri melahirkan sebuah budaya pendidikan yang khas di kalangan pesantren. Hubungan di antara mereka sangat erat, bahkan hubungan mereka diibaratkan dengan seorang anak dengan bapaknya. Santri menganggap kyai sebagai sosok seorang bapak yang memimpin, membimbing, dan mengarahkan jalan hidupnya, sedangkan kyai menganggap santri sebagai anak yang merupakan titipan Tuhan. Seorang kyai dapat melakukan komunikasi dengan siapa saja dan kapan saja. Begitu juga dengan seorang ustadz dan santri. Hanya saja, masing-masing mempunyai etika sendiri yang harus ditaati.

Menilik sejarah eropa di abad pertengahan yang kental dengan kekuasaan dan doktrin gereja dan dominasi gereja yang tujuannya untuk membimbing umat kearah hidup yang saleh, namun disisi lain dominasi gereja ini tanpa memikirkan martabat dan kebebasan manusia yang mempunyai perasaan, pikiran, keinginan, dan cita-cita untuk menentukan masa depannya sendiri.

${ }^{8}$ Zamakhsyari Dhofier, Tradisi Pesantren: Studi tentang Pandangan Hidup Kyai, (Jakarta: LP3ES, 1982), h. 78-80. 
Millatī, Journal of Islamic Studies and Humanities, Vol. 3, No. 1, Juni 2018: 103-124

Karena itu perkembangan ilmu pengetahuan terhambat. Sementara, budaya pendidikan di pesantren memunculkan sebuah kesamaan yang mirip meski tidak sama. Dimana posisi kyai dianggap sebagai wakil tuhan yang terhindar dari kesalahan. Budaya patron klien dalam hubungan antara kyai dan santri. Budaya ini berdampak pada makin besarnya tingginya derajat seorang kyai di mata santri dan pesantren terkendali oleh kepemimpinan kharismatik sang kyai. Sowan dan berkah.dikalangan santri sebagai subyek yang banyak mencari manfaat "berkah" ini akan melakukan berbagai cara untuk mendapatkan berkah dari sang kyai seperti menjadi sopir atau abdi dalem kyai.

Kedua fenomena tersebut saling menyuguhkan dominasi sisi doktrin agama yang mampu menembus lapisan kepercayaan masyarakat dalam berbagai bidang kehidupan. Hal ini menjadi sebuah diskusi yang menarik ketika dunia globalisasi saat ini tidak memberikan ruang-ruang perkembangan praktek doktrin agama, bahkan sebuah perkembangan ilmu pengetahuan dan teknologi dipacunya untuk kebaikan umat manusia dalam memenuhi perkembangan dan peningkatan hidup dari peradaban manusia.

Melalui pembandingan budaya inilah penulis melihat fenomena yang berkembang di dunia pesantren memiliki kemiripan dengan apa yang terjadi pada masa abad pertengahan eropa yaitu abad 10 Masehi sampai 15 Masehi, dimana perkembangan argumentasi, kritik dan ilmu pengetahuan menjadi terpusat pada doktrin-doktrin gereja yang lemah akan perkembangan iptek dan gagal dalam menjawab perkembangan zaman. Disaat yang sama dunia Islam sangat maju pada masa kekhalifahan bani abbasiyah dengan berbagai penemuan penting dalam bidang teknologi. Inilah yang menjadi titik penting menurut penulis dimana kemiripan tersebut perlu dikaji dan ditelusuri dalam sebuah pemikiran yang mendalam tentang relevansi budaya pendidikan di pesantren terhadap tantangan dunia Islam di era globalisasi.

\section{Metode}

Metode yang digunakan dalam penulisan ini adalah Studi Kepustakaan (Library Research). Studi Kepustakaan (Library Research) merupakan penelitian yang dilakukan berdasarkan informasi dari publikasi ilmiah, penelitian terdahulu, ataupun sumber tertulis lain yang mendukung. Sumber informasi utama dalam penelitian ini diperoleh melalui analisis publikasi hasil penelitian sebelumnya dan dokumen lain yang terkait dengan tujuan kajian. Dalam penelitian ini, proses analisa data yang digunakan adalah analisa data kualitatif. Analisis dan 
interpretasi atau penafsiran ini dilakukan dengan merujuk kepada landasan teoritis yang berhubungan dengan masalah penelitian.

\section{Tantangan Dunia Islam di Era Globalisasi}

Era Globalisasi berpandangan bahwa dunia tengah didominasi oleh perekonomian dan munculnya hegemoni pasar dunia kapitalis serta ideologi neoliberal yang menopangnya. Untuk mengimbangi derasnya arus dan tantangan globalisasi, perlu dikembangkan dan ditanamkan karakteristik pendidikan Islam yang mampu berperan dan menjawab tantangan tersebut yakni pesantren. Globalisasi merupakan proses strukturisasi dunia sebagai suatu keseluruhan yang menghadirkan dua kecenderungan yang saling bertentangan, yaitu proses penyeragaman (homogenization) dan pemberagaman (differenciation), sehingga membuat interaksi yang rumit antara hal-hal yang lokal dan global. Globlisasi ditandai oleh menguatnya ruang pribadi. Ruang kebebasan pribadi untuk mengekspresikan pendapat, jati diri, dan kepribadian semakin menyempit karena banyaknya pesanpesan atau tuntutan-tuntutan dari kehidupan modern yang harus dilaksanakan. Akibatnya beban moral semakin berat, seolah-olah tidak ada lagi kemerdekaan pribadi untuk mengembangkan ideide aslinya. Ditambah lagi nilai-nilai lama dijungkirbalikkan dan diganti dengan nilai-nilai baru yang meterialistis. Tak hanya itu, globalisasi ditandai dengan meningkatnya intensitas hubungan antar budaya, norma sosial, kepentingan, dan ideologi antar bangsa. Internet dan satelit-satelit komunikasi menghubungkan banyak negara di dunia seolah seperti sebuah desa yang secara sosiologis sering disebut global village.

Globalisasi mempunyai rangkaian panjang yang saling terhubung dari berbagai aspek. Globalisasi menjadikan kebudayaan Barat sebagai trend kebudayaan dunia.Kebudayaan Barat yang didominasi budaya Amerika yang sarat dengan konsumerisme, hedonisme dan materialisme menjadi kiblat bagi kebudayaan-kebudayaan di negara-negara berkembang. Dalam bentuk lain Haidar Daulaby merumuskan ciri-ciri pergaulan global yang terjadi saat ini dan masa-masa yang akan datang sebagai berikut.

Pertama terjadi pergeseran; dari konflik ideologi dan politik kearah persaingan perdagangan, investasi, dan informasi; dari keseimbangan kekuatan (balance of power) ke arah keseimbangan kepentingan (balance of interest).

Kedua, hubungan antar negara atau bangsa secara struktural berubah dari sifat ketergantungan (dependency) kearah saling tergantung (interdependency); 
Millatī, Journal of Islamic Studies and Humanities, Vol. 3, No. 1, Juni 2018: 103-124

hubungan yang bersifat primodial berubah menjadi sifat tergantung kepada posisi tawar-menawar (bargaining position).

Ketiga, batas-batas geografi hampir kehilangan arti operasionalnya. Kekuatan suatu negara dan komunitas dalam interaksinya dengan negara (komunitas lain) ditentukan oleh kemampuannya mamanfaatkan keunggulan komparatif (comparatif advantage) dan keunggulan kompetitif (competitive advantage)

Keempat, persaingan antar negara saling diwarnai oleh perang antar penguasaan teknologi tinggi. Kelima, terciptanya budaya dunia yang cenderung mekanistik, efisien, tidak menghargai nilai dan norma yang secara ekonomi dianggap tidak efisien.

Persoalan agama merupakan sesuatu yang tidak bisa diabaikan dalam perkembangan globalisasi karena semenjak era renaissance peran agama secara bertahap mulai dikebiri sehingga menjadi tuntutan pada setiap pemuka agama untuk bisa merelevankan ajaran agamanya agar tetap bisa eksis dalam tatanan baru dunia yang semakin global dan kompetitif. Pengaruh globalisasi, tentunya tidak bisa dibatasi hanya pada persoalan yang telah diangkat di atas, tetapi lebih dari itu, langkah pembahasannya merambah hampir semua segi kehidupan. Sebagai umat beragama (Islam), kita harus merespon problem yang muncul sebagai konsekuensi logis dari kehadiran globalisasi. Oleh karenanya, pemahaman bahwa Islam merupakan ajaran global adalah suatu keharusan yang tidak bisa di tawar lagi. ${ }^{9}$ Islam sebagai ajaran agama yang universal mampu menjadi tata nilai sebagai acuan bagi kehidupan yang serba berkembang dan dinamis, sekaligus menunjukan keagungan, keutuhan, dan keunikannya. Pertama, syari'at Islam adalah tata nilai, aturan, dan norma ciptaan Allah SWT, yang mengetahui segala sesuatu yang dibutuhkan oleh manusia. Tata nilai tersebut dibuat sesuai dengan sendi umum kemanusiaan, baik secara individu maupun sosial kemasyarakatan. Tidak mungkin terjadi pertentangan antara ajaran Islam yang bersumberkan wahyu Allah SWT dan fitrah manusia sebagai makhluk-Nya. ${ }^{10}$ Kedua, seluruh tata nilai dalam ajaran Islam dimaksudkan untuk kesejahteraan agar manusia terpelihara agamanya, dirinya, akalnya, kehormatannya, dan harta bendanya.

\footnotetext{
${ }^{9}$ Khusnul Khotimah, "Islam dan Globalisasi: Sebuah Pandangan tentang Universalitas Islam,” Jurnal Komika, Vol.3 No.1 (2009), h.114-132.

10 "Maka hadapkanlah wajahmu dengan lurus kepada (agama) Allah; (tetaplah atas) fitrah Allah yang telah menciptakan manusia menurut fitrah itu. Tidak ada perubahan pada fitrah Allah. (Itulah) agama yang lurus, tetapi kebanyakan manusia tidak mengetahui." (Q.S, al-Rum: 30).
} 
Ajaran Islam tidak pernah menyuruh, kecuali kepada hal-hal yang munkar, tidak pernah melarang kecuali yang mungkar, tidak pernah menghalalkan kecuali yang baik, dan tidak pernah mengharamkan kecuali yang buruk. ${ }^{11}$ Al-Islam minhaj at-taghyir, Islam adalah agama yang menghendaki perubahan, mengeluarkan manusia dari keadaan zhulumat menuju kehidupan yang penuh dengan nur. Ada tiga macam zhulm, yaitu ketidaktahuan tentang syari'at, pelanggaran atas syari'at Allah, dan penindasan. Islam diturunkan untuk membebaskan manusia dari kehidupan yang penuh dengan kemaksiatan menuju ketaatan, dari kebodohan tentang syari'at menuju pemahaman tentang halal, haram, baik, buruk, apa yang sepatutnya dilakukan, dan apa yang tidak. Juga dari kehidupan yang penuh dengan belenggu dan penindasan, menuju kehidupan yang penuh dengan kebebasan, tempat manusia dihargai sebagai manusia yang mempunyai derajat dan kedudukan yang sama di hadapan Allah, yang membedakannya hanyalah ketakwaan kepada-Nya. Ketiga, syumuliyah, yaitu mencakup semua segi kehidupan manusia. Ia adalah ajaran yang berkaitan dengan sistem keyakinan, aturan, moral, pemikiran, ilmu pengetahuan, nilai-nilai kemanusiaan, hukum, sistem keluarga, serta hubungan antarmanusia, yang saling berhubungan dan tidak terpisahkan satu dengan yang lainnya. Unsur-unsurnya disusun sedemikian rupa, mencakup seluruh segi kehidupan, melengkapi segala kebutuhan, dan melindungi segala kegiatan. Dalam lingkup ini, prinsip tauhid merupakan prinsip yang pertama agama Islam, dan prinsip segala yang Islami. Allah itu tunggal secara mutlak dan tertinggi dan secara metafisis dan aksiologis. Dia adalah Sang Pencipta, yang dengan perintah-Nya, segala sesuatu dan peristiwa terjadi. Ia kemudian menjabarkan dari prinsip tauhid ini ke kesatuan alam semesta, kesatuan kebenaran, kesatuan pengetahuan, kesatuan hidup, dan kesatuan umat manusia. ${ }^{12}$ Keempat, tata nilai Islam itu tampil dalam bentuk prinsip-prinsip umum menyeluruh yang melahirkan gerak maju. Sejarah telah menunjukkan kepeloporan umat Islam dalam berbagai bidang kehidupan yang sejalan dengan peningkatan kualitas kemanusiaan itu sendiri. Penguasaan peradaban yang tinggi dilandasi dengan akidah, persamaan, keadilan, persaudaraan, serta nilai-nilai tinggi lainnya.

Pada perkembangannya, arus globalisasi yang kian deras pun berdampak cukup signifikan terhadap berbagai aspek kehidupan. Salah satunya Pesantren sebagai institusi pendidikan yang selalu memegang teguh nilai-nilai kebudayaan

\footnotetext{
${ }^{11}$ Q.S, Al-A'raf: 157.

${ }^{12}$ Didin Hafidhuddin, Dakwah Aktual, (Jakarta: Gema Insani, 1998), h. 22.
} 
Millatī, Journal of Islamic Studies and Humanities, Vol. 3, No. 1, Juni 2018: 103-124

islam didalam pesantren tidak bisa tidak untuk melakukan penyesuaian dengan denyut nadi perkembangan zaman dari dampak globalisasi ini. Namun demikian, pondok pesantren terus berupaya mengimbangi irama dan alur perkembangan zaman dalam rangka menjawab tantangan globalisasi. Bagaimana pondok pesantren menjawab tantang perkembangan zaman dan arus globalisasi dengan berbekal nilai-nilai moral dan budaya yang telah dilestarikan di pesantren mengimbangi perkembangan zaman dan tetap mempertahankan eksistensinya sebagai lembaga pendidikan non formal yang selalu menjunjung nilai-nilai moral. Hal ini menarik untuk ditelusur lebih jauh menilik kentalnya budaya pesantren yang melekat di masyarakat Jawa khususnya Jawa Timur.

Permasalahan fiqh yang sering dihadapi sekarang ini adalah tidak bertemunya antara landasan tekstual yang bersifat normative dengan konteks sosial yang selalu berubah. Salah satu penyebab utamanya adalah perspektif figh yang cenderung formalistik dan tidak terkonsentrasi pada aspek teologis. Perspektif figh tersebut dapat dijelaskan sudah tidak sebanding dengan realitas sosial yang mengarah pada sudut pandang teologis. Teologi dalam hal ini bukan bermakna tauhid yang membuktikan keesaan Tuhan, tetapi teologi dilihat dari pandangan hidup yang menjadi pedoman hidup umat Islam. Di sisi lain, asumsi formalistik tersebut lambat laun tersisihkan oleh hakikat figh itu sendiri. Kecenderungan formalitas itu seakan mulai mengaburkan entitas figh dalam penerapan kehidupan sehari-hari kaum muslimin. Terlebih lagi, jika melihat konstruksi masyarakat Islam Indonesia yang masih sangat kuat dipengaruhi nilai-nilai tradisi peninggalan leluhur. Melalui landasan ini pembahasan akan menitik beratkan relevansi fenomena terhadap tantangan dunia islam di era globalisasi pada berbagai bidang terutama bidang pendidikan.

\section{Tantangan Budaya Pendidikan Islam Pesantren di Era Globalisasi}

Pendidikan Islam merupakan salah satu media paling strategis dalam menciptakan sumber daya manusia yang berkualitas perlu kontektual terefleksi perlunya format baru dalam rangka menyingkapi kondisi masyarakat yang harus direspon serius baik secara konseptual, strategis dan praktis. Sejalan dengan itu, masalah pendidikan menjadi prioritas utama untuk dilaksanakan, karena pada kenyataannya merupakan faktor penentu bagi perkembangan umat islam. Kenyataan lain yang tidak dapat disangkal adalah bahwa komunitas muslim pada zaman modern ini masih mengalami ketertinggalan dibidang pendidikan, dengan demikian salah satu target yang harus di usahakan semaksimal mungkin 
adalah revitalisasi pelaksanaan pendidikan bagi umat islam melalui cara-cara yang sesuai dengan nilai-nilai dan motif ajaran islam, sehingga tidak salah arah dalam pelaksanaan sebagaimana pendidikan ala barat. Tidak ada jalan lain untuk memperbaiki keterpurukan umat islam selain menyusun sistem pendidikan yang berakar pada nilai-nilai, prinsip-prinsip dan tujuan-tujuan islam. ${ }^{13}$

Dalam kehidupan, pendidikan islam memiliki tujuan yang cukup sentral dalam mempersiapkan peserta didik menempuh kesempurnaan insani dalam menghadapi masyarakat yang bermuara pada pendekatan diri kepada Allah SWT. Adapun yang bertujuan jangka pendek diarahkan untuk lebih menekankan pada aspek kebutuhan masyarakat ketika melihat kondisi atau perubahan mayarakat kekinian. Seperti penyiapan tenaga-tenaga profesional, penciptaan nalar kritis peserta didik dalam menganalisa fenomena sosial yang terjadi dimasyarakat dan penyiapan sumber daya manusia sebagai upaya menjawab tantangan zaman dalam dunia pendidikan islam yang membutuhkan sebuah jawaban solutif. ${ }^{14}$

Di tengah arus globalisasi, keberadaan pendidikan Islam dituntut untuk mampu menjadi mitra dalam perkembangan dan pertumbuhan Globalisasi, bukan menjadi serangan yang justru akan berseberangan dengan semakin pesatnya kemajuan. Sebab, era ini akan terus berjalan maju dan tidak akan mengenal siapapun yang akan menjadi penikmatnya, dan kemajuannya akan mampu menggilas dan menggerus apapun yang menghalanginya. Fenomena Globalisasi mau tidak mau akan menciptakan dua keniscayaan, pertama Globalisasi akan menimbulkan Global Village dimana akan terjadi fenomena desa global dimana tidak ada lagi sekat diantara negara-negara yang ada di dunia ini. Namun sebaliknya, fenomena Globalisasi akan memunculkan perampokan global atau yang acapkali disebut Global Pillage dimana negara dengan resources yang besar akan melakukan tindakan kejahatan ekonomi terhadap negara yang kurang maju. Fenomena yang terbangun dengan munculnya era globalisasi telah memberikan berbagai macam problem baik tentang bagaimana informasi yang terus berkembang tanpa pandang bulu dapat diserap atau juga bagaimana mensikapi hal baru yang selalu saja datang silih berganti tanpa adanya filter yang menyaringnya. Era globalisasi dengan teknologi informasinya semakin dapat dirasakan perkembangannya, dengan medianya yang berupa komputer,

${ }^{13}$ Ismail Raji Al-Faruqi, Tawhid: Its Implications for Though and life, (The International Institute of Islamic Thought, 1989), h. 17.

${ }^{14}$ Syamsirin, "Tinjauan Filosofis Tantangan Pendidikan Islam Pada Era Globalisasi," Jurnal At-Ta'dib, Vol.7 No.2 (2012), h. 260. 
Millatī, Journal of Islamic Studies and Humanities, Vol. 3, No. 1, Juni 2018: 103-124

televisi, hand phone, dan peralatan canggih lainnya, telah benarbenar menjadi hal yang komplek dalam transformasi informasi. Pada masyarakat informasi peranan media elektronika sangat memegang peran penting, bahkan menentukan corak kehidupan. Sebab lewat komunikasi satelit, orang tidak hanya memasuki lingkungan informasi dunia, tetapi juga sanggup mengolahnya dan mengemukakannya secara lisan, tulisan, bahkan visual. ${ }^{15}$ Muhammad Tholchah Hasan (2006) mengemukakan tantangan pendidikan Islam yang harus dihadapi di era global ini adalah kebodohan, kebobrokan moral, dan hilangnya karakter muslim.

Oleh karena itu, Islam memberikan anjuran adanya perubahan yang positif dalam keadaan apapun sehingga mengarah pada kemajuan dan perbaikan. Pemahaman yang demikian perlu ditumbuh kembangkan pada cara berfikir peserta didik sebagai generasi kedepan. Memperluas wawasan dan membentuk sikap yang toleran terhadap berbagai perubahan dengan tanpa kehilangan pegangan dan pendirian, sebab perubahan yang terjadi merupakan sunnatullah. Maksudnya, agar peserta didik menjadi generasi yang mampu menyesuaikan diri dan tetap efektif berjuang di tengah perubahan sosial yang mendunia tanpa kehilangan komitmen serta sikap ketakwaan. Dengan demikian, generasi tersebut dapat mengambil posisi subyek yang ikut memainkan peranan dan tidak sekedar menjadi penonton atau tamu di sebuah desa global dengan realitas budaya yang ada. ${ }^{16}$

Melihat berbagai peluang dan tantangan yang ada, maka kedepan perlu dilakukan formulasi bagi pendidikan islam khususnya di pesantren dalam rangka mempersiapkan fenomena globalisasi yang makin hari makin pesat antara lain.

Pertama, Pendidikan semakin dituntut untuk tampil sebagai kunci dalam pengembangan kualitas sumberdaya manusia, yaitu manusia yang mempunyai wawasan, kemampuan dan ketrampilan serta kepribadian yang sesuai dengan kebutuhan nyata yang dihadapi umat.

Kedua, orientasi pada kemampuan nyata yang dapat ditampilkan oleh lulusan pendidikan akan semakin kuat, artinya menciptakan dunia kerja yang cenderung realistisdanpragmatis, di manadunia kerja lebih melihat kompetensi nyata yang dapat ditampilkan.

${ }^{15}$ Abudin Nata, Manajemen Pendidikan: Mengatasi Kelemahan Pendidikan Islam di Indonesia, (Bogor: Kencana, 2003), h. 78.

${ }^{16}$ Ahmad Janan Asifudin, Mengungkit Pilar-pilar Pendidikan Islam (Tinjauan Filosofis), (Yogyakarta : Sunan Kalijaga Press, 2009), h. 83-84. 
Ketiga, mutu pendidikan suatu komunitas atau kelompok masyarakat, tidak hanya diukur berdasarkan kriteria internal saja, melainkan dibandingkan dengan komunitas lain yang lebih riil.

Keempat, apresiasi dan harapan masyarakat dunia pendidikan semakin meningkat, yaitu pendidikan yang lebih bermutu, relevan dan hasilnya pun dapat dipertanggungjawabkan.

Kelima, sebagai komunitas atau masyarakat religius, yang mempunyai keimanan dan tata nilai, maka pendidikan yang diinginkan adalah pendidikan yang mampu menanamkan karakter islami disamping kompetensi lain yang bersifat akademis dan skill. ${ }^{17}$

Salah satu institusi pendidikan islam yang harus melakukan reformulasi pada model pendidikan di tengah arus globalisasi saat ini adalah pesantren. Pesantren di era globalisasi seperti saat ini dituntut untuk mampu memodifikasi antara kebutuhan masyarakat dengan tujuan pesantren sebagai lembaga pembinaan dan pemberdayaan umat. Tentunya, untuk mewujudkan hal ini, pesantren harus bertolak pada paradigma yang digunakan dan melakukan pembaharuan terhadap kekurangan-kekurangannya. Menurut Ahmad Tafsir (2008), dalam Islam ada tiga paradigma besar pengetahuan. Pertama, paradigma sains, pengetahuan yang diperoleh akal dan indera seperti fiqh; kedua, paradigma logis yaitu pengetahuan dengan objek yang abstrak seperti filsafat; dan ketiga, paradigma mistik yang diperoleh dengan rasa. Selama ini pondok pesantren hanya membekali santri paradigma yang pertama dan yang ketiga. Sementara paradigma yang kedua kurang tersentuh. Untuk itu pondok pesantren saat ini harus mampu memasukkan paradigma yang kedua, yaitu paradigma logis, agar semua pengetahuan dapat dibekalkan kepada seluruh peserta didik. ${ }^{18}$

Jika kita meminjam konsep dari Daulay (2004), ciri-ciri pesantren masa depan yang harus menyesuaikan diri dengan perkembangan Globalisasi ada tiga, yaitu: ledakan ilmu pengetahuan dan teknologi, kompetitif, moral dan pluralisme. Pondok pesantren modern idealnya bersikap aktif terhadap perkembangan ilmu pengetahuan, menyuburkan daya saing, tetapi tetap mampu mempertahankan pembinaan moral yang selama ini dianggap prestasi besar pondok pesantren. Kyai ibarat sebagai "raja" di setiap pesantren harus memiliki

${ }^{17}$ Bashori Muchsin dan Abdul Wahid, Pendidikan Islam Kontemporer, (Bandung : PT. Refika Aditama, 2009), h. 68.

${ }^{18}$ Ahmad Tafsir, Ilmu Pendidikan dalam Perspektif Islam, (Bandung: Remaja Rosdakarya, 2008), h. 175. 
Millatī, Journal of Islamic Studies and Humanities, Vol. 3, No. 1, Juni 2018: 103-124

peran sentral dalam menentukan model dan peran pesantren dalam berinteraksi dengan tren kehidupan masyarakat. Apabila konsep seperti ini mampu dilakukan dengan baik, maka pesantren akan semakin tumbuh mengakar kuat dan kredibilitasnya sebagai institusi pendidikan islam akan semakin naik di tengahtengah masyarakat. ${ }^{19}$

\section{Relevansi Budaya “pekewuh” terhadap Kyai di Era Globalisasi}

Dunia sebagai suatu panggung yang menekankan berbagai perubahan dalam peran dan kedudukan (status) yang muncul seiring dengan bergulirnya waktu, kiranya tepat digunakan dalam meneropong kepemimpinan kyai. Dalam konteks ini, kyai merupakan status yang dihormati dengan segudang peran yang dimainkannya dalam masyarakat. Ketokohan dan kepemimpinan kyai sebagai akibat dari status dan peran yang disandangnya, telah menunjukkan betapa kuatnya kecakapan dan pancaran kepribadiannya dalam memimpin pesantren dan masyarakat. Hal ini dapat dilihat dari bagaimana seorang kyai dapat membangun peran strategisnya sebagai pemimpin masyarakat non formal melalui suatu komunikasi intensif dengan masyarakat. Kedudukannya yang penting di lingkungan pedesaan sama sekali bukan hal baru, tetapi justru sejak masa kolonial, bahkan jauh sebelum itu, tampak lebih menonjol dibandingkan dengan masa sekarang yang mulai memudar. ${ }^{20}$

Pesantren, khususnya di Jawa dan Madura, pernah menduduki posisi strategis dalam perspektif masyarakat. Pesantren waktu itu mendapatkan pengaruh dan penghargaan besar karena kemampuannya dalam mempengaruhi masyarakat. Dalam perkembangannya, keperkasaan pesantren dimitoskan karena adanya kharisma kyai dan dukungan besar para santri yang tersebar di masyarakat. ${ }^{21}$

Kyai dengan kharismanya dijadikan imam dalam bidang 'ubudiyah, upacara keagamaan dan sering diminta kehadirannya untuk menyelesaikan problem yang menimpa masyarakat. Rutinitas ini semakin memperkuat peran kyai dalam masyarakat, sebab kehadirannya diyakini membawa berkah. ${ }^{22}$ Sebagai implikasi dari peran yang dimainkan kyai ini, kedudukan pesantren menjadi multi fungsi.

${ }^{19}$ Haidar Putra Daulay, Pendidikan Islam, (Jakarta: Kencana, 2004), h. 75.

${ }^{20}$ Manfred Ziemek, Pesantren dalam perubahan Sosial, (Jakarta: P3M., 1986), h. 138.

${ }^{21}$ Abdurrahman Wahid, "Pesantren sebagai Sub-Kultur", dalam M. Dawam Rahardjo, ed. Pesantren dan Pembaharuan, (Jakarta: LP3ES, 1988), h. 54-55.

${ }^{22}$ Sukamto, Kepemimpinan Kyai dalam Pesantren, (Jakarta: LP3ES., 1999), h. 13. 
Kyai dengan kharisma yang dimilikinya tidak hanya dikategorikan sebagai elit agama, tetapi juga sebagai elit pesantren dan tokoh masyarakat yang memiliki otoritas tinggi dalam menyimpan dan menyebarkan pengetahuan keagamaan Islam serta berkompeten dalam mewarnai corak dan bentuk kepemimpinan terutama dalam pesantren. Tipe kharismatik yang melekat pada dirinya menjadi tolok ukur kewibawaan pesantren. Dilihat dari segi kehidupan santri, charisma kyai merupakan karunia yang diperoleh dari kekuatan dan anugerah Tuhan.

Dari deskripsi tersebut, memunculkan beragam pertanyaan. Dalam konteks era globalisasi dan kekinian, apakah kharisma kyai masih mampu menjadi sumber perubahan sosial? apakah pesan dan pandangannya senantiasa diresponsi masyarakat kita, yang kini, cenderung bergerak ke arah modernitas, meski pun masih dalam taraf proses atau masa transisi.

Oleh karena proses tersebut menjadi milik masyarakat, maka eksistensi pondok pesantren sebagai bagian dari masyarakat tidak lagi sentral. Kedudukan kyai mengalami differensiasi dan tidak lagi menjadi tempat bertumpu, seperti layaknya tempo dulu. Demikian juga kharisma yang pada awalnya bertumpu pada kyai, kini telah dikoyak oleh dinamika perkembangan rasionalitas masyarakat.

\section{Kepemimpinan Pesantren dan "Pekewuh" terhadap Kyai}

Kajian tentang kyai, mesti mengikutsertakan kajian tentang kepemimpinan pesantren, dan mengkaji tentang kepemimpinan pesantren,tidak dapat dilepaskan dari kajian tentang budaya "pekewuh" terhadap Kyai. Kedua hal tersebut-kepemimpinan pesantren dan "pekewuh" terhadap Kyai-menjadi suatu bagian integral yang tidak dapat dipisahkan, sebab di dalamnya terkandung status dan peran yang dimainkan oleh seseorang dengan predikat yang disandangnya dalam suatu masyarakat.

Istilah kyai dalam bahasa Jawa mempunyai pengertian yang luas. Ia berarti mencirikan baik benda maupun manusia yang diukur dalam sifat-sifatnya yang istimewa, dan karenanya, sangat dihormati. Misalnya dikatakan sakti bila sang empu sanggup memasukkan kesaktian pada keris buatannya. Keris-keris semacam itu dijuluki atau diberikan predikat kyai. ${ }^{23}$ Senjata dan benda-benda keramat yang berkekuatan gaib ini selalu dipuja dan diwarisi sebagai sumber kekuatan gaib (pusaka). Bahkan turun dan lenyapnya kekuasaan sosial politik

${ }^{23}$ Ziemek, Pesantren, h. 131. Bandingkan dengan Zamakhsyari Dhofier, Tradisi Pesantren: Studi tentang Pandangan Hidup Kyai, (Jakarta: LP3ES, 1982), h. 55. 
Millatī, Journal of Islamic Studies and Humanities, Vol. 3, No. 1, Juni 2018: 103-124

selalu diterangkan dengan hilangnya pusaka atau karena mengabaikan upacaraupacara yang diperlukan untuk memelihara kesaktian tersebut. ${ }^{24}$

.Di samping dipredikatkan kepada senjata dan benda pusaka, dalam konteks kebudayaan Jawa, gelar kyai juga diberikan kepada laki-laki yang berusia lanjut, arif dan dihormati. Bahkan dalam persebaran agama Kristen, sebutan kyai juga dipakai untuk beberapa pengkabar Injil pribumi, guna membedakannya dengan pengkabar Injil Barat. Namun pengertian kyai dalam konteks Indonesia modern telah mengalami transformasi makna, yakni diberikan kepada pendiri dan pemimpin sebuah pondok pesantren yang membaktikan hidupnya demi Allah serta menyebarluaskan dan memperdalam ajaran-ajaran dan pandangan Islam melalui kegiatan pendidikan. ${ }^{25}$

Oleh karenanya, predikat kyai senantiasa berhubungan dengan suatu gelar yang menekankan kemuliaan dan pengakuan yang diberikan secara sukarela kepada ulama, pemimpin masyarakat setempat sebagai sebuah tanda kehormatan bagi kehidupan sosial dan bukan merupakan suatu gelar akademik yang diperoleh melalui pendidikan formal. ${ }^{26}$

Kemudian, kepemimpinan pesantren yang diidealisasikan sebagai peran yang melekat pada status kekyaian merupakan suatu peran yang mesti dipandang signifikan, sebab kepemimpinan adalah salah satu faktor penting yang mempengaruhi terhadap berhasil atau gagalnya seorang kyai dalam memimpin masyarakatnya, lebih spesifik lagi pada lembaga yang dipimpinnya, pesantren. Tegasnya kepemimpinan merupakan faktor penting yang patut dipertimbangkan. Apabila karakteristik tersebut dikaitkan dengan aktivitas memobilisasi massa, maka lahirlah pemimpin massa (populis), apabila dikaitkan dengan organisasi kedinasan pemerintah, maka disebutlah jabatan pimpinan. Jika dikaitkan dengan bidang administrasi, maka disebutlah administrator. Begitu pula akan muncul sebutan murshid jika dihubungkan dengan organisasi tarekat, dan sebutan kyai jika dikaitkan dengan pondok pesantren, sekalipun tidak semua kyai memimpin

${ }^{24}$ Moebirman, Keris and Other Weapons of Indonesia, (Jakarta: Martinus Nitjhof, 1970), h. 34 .

${ }^{25}$ Kadar semantik dari istilah kyai di sini mencakup secara mutlak komponen tradisional Jawa, termasuk jugapemimpin pesantren. Gelar tersebut berada dalam kesinambungan tradisional dan mencakup arti sebagai sebuahdimensi kerohanian masyarakat yang memiliki suatu kesaktian, misalnya sebagai dukun atau ahli kebatinan dan guru maupun pemimpin di daerah yang berwibawa, yang memiliki legitimasi atas wewenangnya berdasarkan kepercayaan penduduk.

${ }^{26}$ Hiroko Horikoshi, Kyai dan Perubahan Sosial, Terj. Umar Basalim dan Andi Muarly Sunrawa, (Jakarta: P3M., 1987), h. 1-3. 
pondok pesantren. ${ }^{27}$

Hubungan yang melekat antara unsur pribadi dengan sistem sosial ini adalah faktor utama yang mematangkan kepemimpinan tersebut. Ini berarti bahwa selama pribadi yang disebut pemimpin dianggap atau dinilai -oleh masyarakat pengikutnya-telah memenuhi kebutuhan dari sistem sosial dan komunitas pendukungnya, maka selama itu pula ia dapat mempertahankan ikatan emosional di antara para pengikutnya, dan selama itu pula kepemimpinannya tetap berlanjut. ${ }^{28}$

Kepemimpinan kyai, sering diidentikkan dengan atribut kepemimpinan yang melahirkan budaya "pekewuh”. Dalam konteks tersebut, kyai-kyai pondok pesantren, dulu dan sekarang, merupakan sosok penting yang dapat membentuk kehidupan sosial, kultural dan keagamaan warga muslim di Indonesia. Pengaruh kyai terhadap kehidupan santri tidak terbatas pada saat santri masih berada di pondok pesantren, akan tetapi berlaku dalam kurun waktu panjang, bahkan sepanjang hidupnya, ketika sudah terjun di tengah masyarakat.

Mendefinisikan kepemimpinan sebagai usaha untuk mengarahkan perilaku orang lain untuk mencapai tujuan ${ }^{29}$, mempunyai makna bahwa pemimpin memerankan fungsi penting sebagai pelopor dalam menetapkan struktur, keadaan, ideologi dan kegiatan kelompoknya. Sehubungan dengan ini, terdapat tiga perspektif dalam memahami fenomena kepemimpinan. Pertama, kepemimpinan dapat dipandang sebagai kemampuan yang ada dalam diri individu. Hal ini berarti aspek tertentu dari seseorang telah memberikan suatu penampilan berkuasa dan menyebabkan orang lain menerima perintahnya sebagai sesuatu yang mesti diikuti. Ia diyakini memperoleh bimbingan "wahyu", memiliki kualitas yang dipandang sakral dan menghimpun massa dari masyarakat kebanyakan.

Dalam perspektif Max Weber, kepemimpinan yang bersumber dari kekuasaan luar biasa disebut kepemimpinan kharismatik atau charismatic authority $^{30}$ Kepemimpinan jenis ini didasarkan pada identifikasi psikologis seseorang dengan orang lain. Kedua,bentuk kepemimpinan terletak bukan pada

${ }^{27}$ Sukamto, Kepemimpinan Kyai, h. 19

${ }^{28}$ Taufik Abdullah, Islam dan Masyarakat: Pantulan Sejarah Indonesia, (Jakarta: LP3ES., 1987), h. 64 .

${ }^{29}$ Franklin S. Haiman, Leadership and Democratic Action, (Houghton: Mifflin Company, 1971), h. 228.

${ }^{30}$ Max Weber, The Theory of Social and Economic Organization,. Terj. Talcott Parson, (New York: The Free Press,1966), h. 358. 
Millatī, Journal of Islamic Studies and Humanities, Vol. 3, No. 1, Juni 2018: 103-124

diri kekuasaan individu, melainkan dalam jabatan atau status yang dipegang oleh individu. Dalam perspektif Weber, kekuasaan yang bersandar pada tata aturan disebut sebagai legal authority. Pola aturan normatif dan hak memerintah dari pemimpin yang terpilih berdasarkan pola aturan yang sah. Ketiga, bentuk kepemimpinan tradisional, yang bersumber pada kepercayaan yang telah mapan terhadap kesakralan tradisi kuno. Kedudukan pemimpin ditentukan oleh kebiasaan-kebiasaan lama yang dilakukan oleh kelompok masyarakat dalam melaksanakan berbagai tradisi.

Berdasarkan penjelasan Max Webber, ketiga bentuk kepemimpinan tersebut melekat erat dalam budaya "pekewuh" terhadap kyai di pesantren. Budaya ini tumbuh subur dengan diikuti factor-faktor internal dan eksternal yang berkembang. Pada perkembangannya budaya "pekewuh" pada kyai menjadi model khas yang akan ditemukan di daerah-daerah tradisional dengan pesantren menjadi bagian penting dari lapisan sosial masyarakat tersebut.

\section{Krisis, Memudarnya Budaya “pekewuh” terhadap Kyai di Era Globalisasi}

Di atas telah dinyatakan bahwa eksistensi budaya "pekewuh" di pesantren lebih banyak terjadi pada masyarakat tradisional, yang jauh dari rasionalitas serta terjadi karena suasana chaos yang memerlukan pemecahan secara cepat untuk mengembalikan keadaan menjadi stabil. Lalu bagaimanakah eksistensi kepemimpinan yang melahirkan budaya "pekewuh" tatkala masyarakat telah memasuki zaman modern. Sehubungan dengan zaman modern, setidaknya terdapat dua ciri mendasar, pertama, semakin hilangnya pengaruh institusi agama, kedua, semakin tingginya supremasi rasionalitas sains.

Modernisasi menimbulkan globalisasi, sehingga disadari atau tidak, kemajuan yang ditimbulkannya secara meyakinkan mengubah dan mengarahkan kebudayaan manusia dan bahkan melebihi angan-angan manusia. Dalam konteks ini, Lucian W. Pye menyatakan bahwa modernitas adalah budaya dunia. Menurutnya, proses mondial ini tercipta karena kebudayaan modern senantiasa didasarkan kepada pertama teknologi yang maju dan semangat dunia ilmiah; kedua pandangan hidup yang rasional; ketiga pendekatan sekuler dalam hubungan-hubungan sosial; keempat rasa keadilan sosial dalam masalah-masalah umum (public affairs), terutama dalam bidang politik dan keenam menerima keyakinan bahwa unit utama politik mesti berupa negara-negara kebangsaan. ${ }^{31}$

31 Lucian W. Pye, Aspect of Political Development, (Boston: Little Brown, 1965), h. 8 
Pada taraf individual, manusia modern senantiasa memiliki sifat-sifat: kesiapan untuk menerima pengalaman-pengalaman baru dan keterbukaan kepada pembaharuan; kecenderungan untuk membentuk opini mengenai sejumlah masalah dan isu yang muncul tidak hanya di lingkungan dekat, tetapi juga di luarnya; orientasi di bidang opini lebih bercorak demokratis; lebih berorientasi pada masa kini dan masa depan dari pada masa lampau; berpijak pada perencanaan dan organisasi dalam menangani kehidupan; efektif; menjunjung harkat diri dan senantiasa memberikan penghargaan terhadap prestasi orang lain; berkeyakinan pada ilmu dan teknologi dan memegang teguh keyakinan terhadap keadilan distributif. 32

Hal tersebut sangat bertentengan dengan apa yang telah berjalan di pesantren. Budaya "pekewuh" sangat bertolak belakang dengan semangan rasionalitas dan globalisasi yang mengarah pada modernisasi pemikiran, ilmu pengetahuan dan cara melihat sudut pandang pada sebuah fenomena. Terbentuknya masyarakat modern sebagai akibat modernisasi dengan berbagai karakteristiknya tersebut merupakan suatu tantangan sekaligus ancaman terhadap budaya "pekewuh" terhadap kyai. Dalam hal ini, setidaknya terdapat beberapa faktor penting yang mempengaruhi pudarnya bahkan hilangnya budaya "pekewuh" terhadap kyai. ${ }^{33}$

Pertama, munculnya generasi muda santri yang berkarakter modern, dalam pengertian bahwa mereka mempunyai kemampuan dan kebebasan yang lebih besar untuk mengkaji dan mengevaluasi sikap kiai, paling tidak dalam wilayah politik. Perubahan seperti itu, jelas melahirkan masalah yang berkaitan dengan legitimasi peran kepemimpinan kiai. Kelahiran santri modern ini adalah hasil dari program moderniasai dalam sistem pendidikan pesantren yang ditandai dengan semakin bertambahnya jumlah sekolah dalam lingkungannya.

Kedua, meningkatnya jumlah kelas menengah muslim yang lebih terdidik. Munculnya intelektual-intelektual muda, baik yang sekular maupun yang religius di kalangan pesantren tidak hanya membuat posisi kiai sebagai legitimator menjadi tersaingi, tetapi juga membuat kredibilitas dan otoritasnya menjadi dipertanyakan. Situasi ini menunjukkan bahwa di pedesaan Jawa dan Madura dan juga di internal pesantren, sekarang ini orang-orang dapat pergi

${ }^{32}$ Said Aqiel Siraj, "Khazanah Pemikiran Islam dan Peradaban Modern”, dalam Marzuki Wahid et.al., Pesantren Masa Depan: Wacana Pemberdayaan dan Transformasi Pesantren, (Jakarta: Pustaka Hidayah, 1999), h. 28.

${ }^{33}$ Endang Turmudi, Perselingkuhan Kiai dengan Kekuasaan, (Yogyakarta: LKiS, 2004), h. 3-4. 
Millatī, Journal of Islamic Studies and Humanities, Vol. 3, No. 1, Juni 2018: 103-124

ke berbagai agen yang dapat memberikan kepada mereka pengetahuan tentang Islam dan kepemimpinan dalam pengertiannya yang lebih umum.

Ketiga, meluasnya wilayah operasi negara di balik peningkatan kualitas kehidupan umat Islam. Negara sangat peduli dengan problem ketidak-setaraan (inequality) dan ia terlibat dalam berbagai hal yang sebelumnya berada di bawah kepedulian kiai. Pengenalan upaya pengendalian angka kelahiran misalnya, telah melibatkan negara dalam pendefinisian arti sosial kelahiran, yang secara tradisional sebelumnya berada di bawah wilayah agama, dimana kiai memainkan peran penting di dalamnya.

Faktor-faktor di atas, tidak hanya melahirkan kalangan Islam muda yang kritis terhadap kepemimpinan kiai, tetapi juga memberikan alternatif mengenai adanya bentuk-bentuk kepemimpinan yang lain. Posisi kiai dan kepemimpinan yang melahirkan budaya "pekewuh" kemudian berubah secara tidak terelakkan, sehingga bukan merupakan suatu kebetulan misalnya, jika seorang kiai didemo oleh santri dan masyarakat sekitarnya.

Dalam fenomena ini, tampak jelas bahwa posisi kiai yang kharismatik dan sekaligus terhormat sudah goyah dan kurang relevan dengan arus modernisasi juga globalisasi dengan sebab yang tidak hanya bersumberkan pada perilaku kiai yang "kurang patut diteladani", tetapi juga -hingga batas tertentu- karena adanya perubahan dalam norma sosial yang melandasi hubungan sosial di antara komunitas umat Islam.

\section{Penutup}

Berdasarkan kajian di atas dapat disimpulkan bahwa pertama, kepemimpinan di pesantren dengan budaya "pekewuh" tokoh keagamaan Islam (kiai) terdapat pada masyarakat yang masih tradisional. Kedua, kepemimpinan yang melahirkan budaya "pekewuh" kiai pada masyarakat transisi -apalagi pada masyarakat modern dan masyarakat metropolis- telah mengalami krisis legitimasi, irrelevant sense di era globalisasi, dan perubahan secara degradatif, karena berbagai dinamika dan perubahan yang terjadi, baik yang bersifat internal pesantren maupun dinamika eksternal komunitas Muslim, dalam maknanya yang luas.

Dengan melihat perubahan status tersebut, sudah selayaknya, dalam dinamika kehidupan sosio-kultural yang dinamis ini, kiai, mau tidak mau pertama, melakukan kaji ulang terhadap statusnya, yakni berusaha melakukan retrospeksi bahwa dirinya kini bukan satu-satunya institusi tempat masyarakat 
bertanya mengenai problem kehidupan, sebab kini telah tumbuh dan berkembang berbagai rujukan yang dapat menjawab berbagai problem yang dihadapi oleh masyarakat. Kedua pada sisi lain, kiai juga mesti menyadari bahwa perubahan sikap masyarakat terhadap lembaga keulamaan ini, merupakan akibat logis dari perubahan-perubahan besar dalam struktur sosial, sehingga -suka atau tidak - mereka perlu menyesuaikan diri dengan situasi yang sedang berubah jika ingin kepemimpinannya terus diterima oleh umat Islam, meskipun tidak berada dalam arah kharismatik lagi. Ketiga dengan fenomena demikian, sudah waktunya bagi kiai -dan calon-calon kiai-untuk melakukan reorientasi terhadap pola kepemimpinan yang diperankannya dari religio paternalistic ke arah pola kepemimpinan partisipatif persuatif.

Pada sisi lain, sesuai dengan perubahan orientasi pola kepemimpinan, ikhtiar meningkatkan kualitas kepribadian dan wawasan intelektualitasnya, misalnya dengan melakukan studi lanjut (post graduate) di lembaga pendidikan formal, yang dengan bekal demikian, kiai menjadi lebih siap-dalam arti tidak gagap dan tidak mengalami post power syndrome- dalam melakukan reposisi fungsi sosialnya di tengah derasnya dinamika perubahan yang tidak lagi berpihak padanya untuk diperlakukan sebagai figur kharismatik lagi oleh komunitasnya.

\section{Daftar Pustaka}

Abdullah, Taufik, Islam dan Masyarakat: Pantulan Sejarah Indonesia, Jakarta: LP3ES., 1987.

Ahmad, Tafsir Ilmu Pendidikan dalam Perspektif Islam, Bandung: Remaja Rosdakarya, 2008.

Anderson, Benedict ROG, Gagasan tentang Kekuasaan dalam Kebudayaan Jawa ter. Ali As'ad, Semarang: Menara Kudus, 1972.

Asifudin, Ahmad Janan, Mengungkit Pilar-pilar Pendidikan Islam (Tinjauan Filosofis), Yogyakarta : Sunan Kalijaga Press, 2009.

Daulay, Haidar Putra, Pendidikan Islam, Jakarta: Kencana, 2004.

Dhofier, Zamakhsyari, Tradisi Pesantren: Studi tentang Pandangan Hidup Kyai, Jakarta: LP3ES, 1982.

Dhofier, Zamakhsyari, Tradisi Pesantren: Studi tentang Pandangan Hidup Kyai, Jakarta: LP3ES, 1982.

Geertz, Clifford, Agama Jawa: Abangan, Santri, Priyayi Dalam Kebudayaan Jawa, Jakarta: Komunitas Bambu, 2013. 
Millatī, Journal of Islamic Studies and Humanities, Vol. 3, No. 1, Juni 2018: 103-124

Hafidhuddin, Didin, Dakwah Aktual, Jakarta: Gema Insani, 1998.

Haiman, Franklin S., Leadership and Democratic Action, Houghton: Mifflin Company, 1971.

Horikoshi, Hiroko, Kyai dan Perubahan Sosial. Ter. Umar Basalim dan Andi Muarly Sunrawa, Jakarta: P3M., 1987.

Karim, Abdul, Sejarah Pemikiran dan Peradaban Islam, cetakan II Sleman Yogyakarta: Penerbit Pustaka Book Publisher, 2009.

Khotimah, Khusnul, "Islam dan Globalisasi: Sebuah Pandangan tentang Universalitas Islam” Jurnal Komika Vol.3 No.1 (Januari-Juni 2009).

Kluckhohn, C, Universal Categories of Culture. Antropology Today, A.L Kroeber Editor Chicago: University Press, 1953.

Moebirman, Keris and Other Weapons of Indonesia, Jakarta: Martinus Nitjhof, 1970.

Muchtarom, Zaini, Santri dan Abangan di Jawa, Jakarta: INIS, 1988.

Muchsin, Bashori, Pendidikan Islam Kontemporer, Bandung : PT. Refika Aditama, 2009.

Nata, Abudin, Manajemen Pendidikan: Mengatasi Kelemahan Pendidikan Islam di Indonesia, Bogor: Kencana, 2003.

Pye, Lucian W., Aspect of Political Development, Boston: Little Brown, 1965.

Raji Al-Faruqi, Ismail, TAWHID. Its Implications for Though and life, (The International Institute of Islamic Thought, 1989.

Siraj, Said Aqiel, "Khazanah Pemikiran Islam dan Peradaban Modern", dalam Marzuki

Wahid et.al., Pesantren Masa Depan: Wacana Pemberdayaan dan Transformasi Pesantren, Jakarta: Pustaka Hidayah, 1999.

Sukamto, Kepemimpinan Kyai dalam Pesantren, Jakarta: LP3ES., 1999.

Syamsirin, "Tinjauan Filosofis Tantangan Pendidikan Islam Pada Era Globalisasi" Jurnal At-Ta'dib Vol.7 No.2 (Desember 2012).

Turmudi, Endang, Perselingkuhan Kiai dengan Kekuasaan, Yogyakarta: LKiS, 2004.

Turner, Bryan S., Sosiologi Islam: Suatu Telaah Analisis atas Tesa Sosiologi Weber. Ter. Machnun Husein, Jakarta: Rajawali, 1984.

Wahid, Abdurrahman, "Pesantren sebagai Sub-Kultur", dalam M. Dawam Rahardjo, ed. Pesantren dan Pembaharuan, Jakarta: LP3ES, 1988.

Weber, Max, The Theory of Social and Economic Organization. Ter. Talcott Parson, New York: The Free Press, 1966.

Ziemek, Manfred, Pesantren dalam perubahan Sosial, Jakarta: P3M., 1986. 